Historic, Archive Document

Do not assume content reflects current scientific knowledge, policies, or practices. 

UNITED STATES DEPARTMENT OF AGRICULTURE

Agricultural Research Service

Animal Husbandry Research Division

\section{PARTIAL LIST OF PUBLICATIONS CONCERNING EQUITATION, RIDING AND TRAINING OF HORSES}

Bosworth, Clarence Edwin. 1939. Breeding your own or raising colts for pleasure and profit. Derrydale Press, New York. 245 pp. (Deals with the care of the mare and foal and the handling and training of foal from birth through each successive year. Contains a chapter on "higher education" and one on "problem horses".)

Burch, Preston M., with the assistance of Alex Bower. 1953. Training Thoroughbred horses. The Blood Horse, Lexington, Ky. 124 pp. Approx. price: $\$ 6.00$.

Burnham, H. S. 1937. Horsemanship. American Horseman, Lexington, Ky. $83 \mathrm{pp}$. (A reprint of articles appearing in The American Horseman of Lexington, under the titles: "From hands to mouth", "What of the five saddle gaits", "The gaits of our American Saddle Horse, their uses and abuses", and "Performance stakes". These articles were written in response to requests for information relative to the origin, breeding, evolution, development and exhibition of the American Saddle Horse.)

Chamberlain, Harry D. (Brigadier General, United States Army). 1937. Riding and schooling horses. Derrydale Press, New York. 199 pp. Approx. price: $\$ 5.50$.

- 1952. Training hunters, jumpers, and hacks. D. Van Nostrand Co., Inc., New York. 329 pp. Approx price: \$6.95. (A digest of breaking the colt and of advanced training and schooling the horse to jump. Also discusses conformation, gaits and physical defects.)

Collins, Robert $W .1938$. Race horse training (Venture all). The Blood Horse, Lexington, Ky. $312 \mathrm{pp}$. Approx. price: $\$ 5.50$. A new reprint edition in 1962.

Dillon, Jane Marshal1. 1958. School for young riders. D. Van Nostrand Co., Inc., Princeton, N.J. 235 pp. Approx. price: \$6.50.

Felton, W. Sidney. 1962. Masters of equitation. J. A. Allen \& Co., Ltd., London. 112 pp. Approx. price: \$5.25. (A book for serious students of equitation as well as for other readers wanting a list of recommended books or horsemanship.) 

Gorman, John Alexander. 1949. The Western horse; its types and training. Interstate Printers and Publishers, Danville, Ill. 390 pp. Approx. price: \$3.50. (Covers the various breeds of Western horses. It also covers the training and management of the colt and work horse through "bronc busting" and "trick riding".)

- 1960. Horses--their breeding, care and training. Wyoming Agr. Exp. Sta. Circ. No. 72. Univ. of Wyoming, Laramie, Wyo. 44 Pp.

Jasper, Mrs. A. William, 1958. Horsemanship. Boy Scouts of America Publication No. 3298A. Boy Scouts of America, New Brunswick, N.J. 68 pp. Approx. price: 25c. (A booklet written for Boy Scouts. Contains sections on: before riding, equipment; facts about the horse; handling horses; the horse in motion; the horse's health; and references for recommended reading.)

Kearley, B. L. 1957. Riding made easy. Country Life Ltd., London. 125 pp., illus. Approx. price: \$5.50. (A picture book ... produced primarily to assist the beginner of moderate means.)

Littauer, Vladimir S. 1946. Modern horsemanship for beginners. Garden City Publishing Co., New York. (A reprint of "Riding forward", published by William Morrow \& Co. Advice on learning to ride, learning to jump and the proper use of equipment.)

- 1951. Comonsense horsemanship. D. Van Nostrand Co., Inc., Princeton, N.J. 333 pp. Approx. price: \$7.50. (A technical book, which the author states is a summing up of that learned in 24 years of teaching riding, on training and equitation with a section on the teaching of riding. Precepts are based on "forward" riding and a "relaxed" horse rather than a "collected" one.)

- 1953. Be a better horseman. Hurst and Blackett, New York and London. 304 pp. Approx. price: \$7.50. (Illustrated with 218 photographs. Written in conversational narrative style with chapters on hacking, jumping, conformation, general schooling, foxhunting and teaching of the forward seat.)

- 1956. Schooling your horse. D. Van Nostrand, Co., Inc., Princeton, N.J. 177 pP. Approx. price: \$5.00. (The aim of the book as stated is to present a distinct and simple method of schooling hunters and jumpers, a method which ... is exceptionally suitable for training country hacks ...; ; the book is geared for the average rider who plans to school an average horse ... for foxhunting and ordinary amateur shows; it does not aim at international competition. "Forward" riding and "forward" schooling are basic to the teachings.)

1962. Horseman's progress. The development of modern riding. D. Van Nostrand Co., Inc., Princeton, N.J. Approx. price: $\$ 7.50$. (An organized review of educated riding.) 

McTaggart, M. F. (Lt. Col.). 1925. Mount and man. Country Life Ltd., London.

- 1928. From colonel to subaltern. Country Life Ltd., London, also Charles Scribner Sons, New York. Republished in 1938 as "Two horsemen and Mable".

Santini, Piero (Major, Italian Cavalry Reserve). 1936. The forward impulse. Huntington Press, New York. 119 pp.

- 1950. Riding reflections. 2d ed. Derrydale Press, New York. - 1952. The riding instructor. Country Life Ltd, London. 161 Pp.

Saunders, George C. 1954. Your horse-his selection, stabling and care. D. Van Nostrand Co., Inc., New York. 207 pp. Approx. price: \$5.50. (A manual for one who must act as his own stableman and groom, written by an experienced horseman who takes care of his own horses singlehanded. It attempts to cover every problem the horse or pony owner will meet.)

Self, Margaret Cabel1. 1952. Horsemastership. Methods of training the horse and the rider. A. S. Barnes and Co., New York. 440 pp. Approx. price: $\$ 5.00$. (Describes many different techniques and methods which can be used by the trainer to train the horse or by the teacher in teaching the child or the adult. Also has a section devoted to a listing of organizational equestrian rules.)

Seunig, Waldemar. 1956. Horsemanship. Doubleday and Co., Inc., Garden City, N.Y. 390 PP. Approx. price: \$8.50. (Originally published in German in 1941 with a 2d ed. in 1948; this 3d ed. is a translation by Leonard Mims. The author states: "the book is intended chiefly as a guide and counsel to the trainer of the young horse coming from the pasture. It accompanies horse and rider until the training goal has been reached ..."; discussions include both cavalry and saddle horse and, on a higher level, the dressage horse.)

Souza, Baretto de (Count). 1922. Elementary equitation. E. P. Dutton \& Co., New York.

- 1926. Advanced equitation. E. P. Dutton \& Co., New York. 419 pp. - 1935. Horseback riding made easy. E. P. Dutton \& Co., New York $120 \mathrm{pp}$.

Wright, Gorden. 1960. Learning to ride, show and hunt. Garden City Books, Garden City, N.Y. 124 pp. Approx. price: $\$ 5.00$. 
Wynmalen, Henry. 1938. Equitation. Country Life Ltd., London, also Charles Scribner's Sons, New York. 144 pp.

- 1958. Dressage. 2d ed. (1st ed. in 1953). Museum Press, London. 280 pp. Approx. price: $\$ 4.20$. (A study of the finer points of riding.)

Young, John Richard. 1954. The schooling of the Western horse. University of Oklahoma Press, Norman, Okla. 322 pp. Approx. price: \$4.95. (A practical handbook, the fundamental purpose of which, as stated by the author, is to give the reader food for thought. It treats the fundamental phases of horse training in general and covers all phases of training and schooling of Western horses.)

This list is not complete. No discrimination is intended against those publications that are not included. 
